\title{
Production and quality of mango fruits cv. Tommy atkins fertigated with potassium in semi-arid region
}

\author{
Marcio Alves Carneiro', Augusto Miguel Nascimento Lima², Ítalo Herbert Lucena Cavalcante², \\ Karla dos Santos Melo de Sousa ${ }^{2}$, Fernanda Campos Alencar Oldoni ${ }^{3}$, Karine da Silva Barbosa ${ }^{2}$
}

Abstract-Correct management of potassium (K) fertilization is of fundamental importance for mango orchards, and $\mathrm{K}$ is one of the most exported and yield-limiting nutrients. Thus, an experiment was carried out to evaluate the production and physical-chemical characteristics of Tommy Atkins mango fruits under fertigation with different doses of potassium chloride and potassium sulfate in the semi-arid region. The experimental design was randomized blocks in split plots, using five $\mathrm{K}$ doses $(50,75,100,125$ and $150 \%$ of the recommended dose) in the plots and two sources of $\mathrm{K}$ (potassium chloride $-\mathrm{KCl}$ and potassium sulfate $-\mathrm{K}_{2} \mathrm{SO}_{4}$ ) in the subplots, with four replicates. The following characteristics were evaluated: transverse and longitudinal diameters, skin thickness, fruit weight, production per plant, pulp percentage, hydrogen potential (pH), soluble solid (SS), ascorbic acid (VIT C), titratable acidity (TA) and $\mathrm{SS} / \mathrm{TA}$ ratio. The doses and sources of $\mathrm{K}$ applied through fertigation caused significant effect on fruit physical-chemical characteristics and production per plant in Tommy Atkins mango, particularly at the dose of $349 \mathrm{~g} \mathrm{plant}^{-1}$ of $\mathrm{K}_{2} \mathrm{SO}_{4}$, which led to higher production per plant and guaranteed the minimum quality required for fruit physical-chemical characteristics.

Index terms: Mangifera indica L., soil fertility, physical-chemical characteristics.

\section{Produção e qualidade de frutos de mangueira cv. Tommy atkins fertirrigada com potássio no semiárido}

\begin{abstract}
Corresponding author: augusto.lima@univasf.edu.br

Received: March 27, 2018. Accepted: July 05, 2018.

Copyright: All the contents of this journal, except where otherwise noted, is licensed under a Creative Commons Attribution License.
\end{abstract}

\begin{abstract}
Resumo - O correto manejo da fertilização potássica é de fundamental importância para os pomares de mangueira, sendo o potássio $(\mathrm{K})$ um dos nutrientes mais exportados e que mais limita a produtividade. Nesse sentido, um experimento foi desenvolvido com o objetivo de avaliar a produção e as características físico-químicas dos frutos da mangueira 'Tommy Atkins' fertirrigada com diferentes doses de cloreto e sulfato de potássio no Semiárido. O delineamento experimental adotado foi o em blocos casualizados, em esquema de parcelas subdivididas, utilizando cinco doses de potássio $(50 ; 75 ; 100 ; 125$ e $150 \%$ da dose recomendada) nas parcelas e duas fontes de potássio: cloreto de potássio $(\mathrm{KCl})$ e sulfato de potássio $\left(\mathrm{K}_{2} \mathrm{SO}_{4}\right)$ nas subparcelas, com quatro repetições. As características avaliadas foram: diâmetros transversal e longitudinal, espessura da casca, peso do fruto, produção por planta, percentual da polpa, potencial hidrogeniônico (pH), sólidos solúveis (SS), ácido ascórbico (VIT C), acidez titulável (AT) e relação SS/AT. As doses e fontes de K aplicadas via fertirrigação promoveram efeito significativo para as características físico-químicas e produção por planta dos frutos da mangueira 'Tommy Atkins', sendo destacada a dose de $349 \mathrm{~g} /$ planta $^{-1}$ de $_{2} \mathrm{SO}_{4}$, a qual apresentou maior produção por planta e garantiu a qualidade mínima exigida para as características físico-químicas dos frutos.
\end{abstract}

Termos para indexação: Mangifera indica L., fertilidade do solo, características físicoquímicas.

\footnotetext{
'Instituto Federal de Educação, Ciência e Tecnologia do Maranhão. São Raimundo das Mangabeiras-MA. Brasil. E-mail: marcio.carneiro@ifma.edu.br ${ }^{2}$ Universidade Federal do Vale do São Francisco. Petrolina-PE. Brasil. E-mails: augusto.lima@univasf.edu.br; italo.cavalcante@univasf.edu.br; karla.smsousa@univasf.edu.br; karynebosa@hotmail.com

3nniversidade Estadual Paulista "Júlio de Mesquita Filho" - Câmpus Araraquara. Araraquara-SP. Brasil. E-mail: fernandac.alencar2010@gmail. com
} 


\section{Introduction}

The Sub-middle São Francisco River Valley, located in the northeastern semi-arid region, accounts for more than $93 \%$ of the Brazilian exports of mango, especially the cv. Tommy Atkins, considered as the most planted in the region (OLIVEIRA et al., 2014).

Despite the economic importance of mango for the São Francisco River Valley and for Brazil, potassium fertilization management in this crop is not yet a consensus in the scientific literature and, commercially, is not performed according to cultivar, despite the differences in the demand especially for 'Keitt' (ALMEIDA et al., 2015), 'Palmer' (CAVALCANTE et al., 2016) and Tommy Atkins (CARNEIRO et al., 2017).

Potassium $(\mathrm{K})$ is one of the most exported nutrients by mango trees (PINTO et al., 2010) and, in a study conducted with the cv. Tommy Atkins in the São Francisco River Valley, the authors found that, in highyielding orchards, $\mathrm{K}$ is the second most limiting nutrient for fruit yield and quality. $\mathrm{K}$ application influences fruit size, appearance, color, and acceptance by consumers, besides leading to high contents of juice, vitamin $\mathrm{C}$ and to their uniformity (GANESHAMURTHY et al., 2011). Several studies have been conducted aiming to correlate the effect of different doses and sources of $\mathrm{K}$ with fruit yield and quality in 'Amrapali' mango (DUTTA et al., 2011), 'Vitória' pineapple (CAETANO et al., 2013) and 'Paluma' guava (AMORIM et al., 2015). Mango postharvest quality depends on various factors, particularly on nutrient balance (AULAR; NATALE, 2013; COSTA et al., 2011).

Given the above, the present study aimed to evaluate the production and physical-chemical characteristics of mango fruits cv. Tommy Atkins fertigated with different doses of potassium chloride and potassium sulfate.

\section{Material and methods}

\section{Mango plants and growth conditions}

Eleven-year-old plants of mango (Mangifera indica L.), cv. Tommy Atkins, with uniform size and vigor were used in the study.

The study was carried out in a commercial mango orchard at the Fazenda Herculano Agrícola farm, in two production cycles (First cycle: January to March 2014; Second cycle: January to March 2015), located in the municipality of Casa Nova - Bahia, Brazil, at geographic coordinates $9^{\circ} 11^{\prime} 43.5$ ' $\mathrm{S}, 41^{\circ} 01^{\prime} 59.2$ ' $\mathrm{W}$ and altitude of $400.3 \mathrm{~m}$. According to Köppen's classification, the local climate is Bswh' (semi-arid). Along the experiment, the mean values of air temperature and relative humidity ranged from $23.48{ }^{\circ} \mathrm{C}$ to $31.26^{\circ} \mathrm{C}(2014)$ and $24.54{ }^{\circ} \mathrm{C}$ to $30.80{ }^{\circ} \mathrm{C}(2015)$ and from $44.5 \%$ to $87.75 \%$ (2014) and
$39.75 \%$ to $90.00 \%$ (2015), respectively, with accumulated precipitation of $304.2 \mathrm{~mm}$ (2014) and $189.86 \mathrm{~mm}$ (2015). The soil of the area is classified as Quartzipsamments (SANTOS et al., 2013).

Before the experiment, under the crown projection of the mango trees, 20 simple soil samples were collected in the 0.0-0.04 m layer to form a composite sample in order to characterize soil fertility and determine soil texture, according to the methodology of Silva (2009) (Table 1).

Mango plants, spaced by $10 \mathrm{~m}$ between rows and $7 \mathrm{~m}$ between plants, were daily irrigated by microsprinklers, with one emitter per plant at $60 \mathrm{~L} \mathrm{~h}^{-1}$ flow rate. All management practices, such as pruning, control of weeds, pests and diseases, application of gibberellininhibitor growth regulators $\left(\mathrm{Cultar}^{\circledR}\right)$ and dormancy breaking (calcium nitrate), were carried out by following the instructions of Genú \& Pinto (2002). Fertilization was applied through a fertigation system, based on soil analysis (Table 1) and plant requirement (GENÚ; PINTO, 2002).

\section{Experimental design and treatments}

The experimental was set up in a randomized block design in split plots, with four replicates, using five $\mathrm{K}$ doses $(50,75,100,125$ and $150 \%$ of the recommended dose) in the plots and two $\mathrm{K}$ sources $\left(\mathrm{KCl}\right.$ and $\mathrm{K}_{2} \mathrm{SO}_{4}$, with respective $\mathrm{K}_{2} \mathrm{O}$ concentrations of 60 and $50 \%$ ) in the subplots. The recommended dose of $\mathrm{K}_{2} \mathrm{O}$ was $180 \mathrm{~g} \mathrm{plant}^{-1}$, according to soil analysis (Table 1) and recommendations of Genú \& Pinto (2002). Each experimental plot comprised five plants, and the central plant was used for evaluation. $\mathrm{K}$ doses were split and applied by fertigation: $45 \%$ before induction, $20 \%$ at flowering, $20 \%$ after fruit setting and $15 \%$ fifty days after fruit setting, as recommended by Genú \& Pinto (2002).

\section{Parameters evaluated and statistical analysis}

Production of fruits per plant was determined by using a Filizola ${ }^{\circledR}$ CF15 precision scale ( 0.5 g precision) and expressed in kilograms per plant $\left(\mathrm{kg} \mathrm{plant}^{-1}\right)$. Marketable fruits were harvested by hand in a single day when they reached minimum size of $15 \mathrm{~cm}$ and physiological maturity, characterized by pulp color (creamy yellow), according to the parameter of fruit selection recommended by the Brazilian Program for Horticulture Modernization (Programa Brasileiro para a Modernização da Horticultura, 2004) for commercial farms.

Then, the fruits were washed, sanitized with sodium hypochlorite solution $\left(200 \mathrm{mg} \mathrm{L}^{-1}\right)$, washed again in running water to remove the excess solution, and stored under refrigeration at $10{ }^{\circ} \mathrm{C}$ for 30 days to complete their maturation cycle. Analyses of mango fruits followed the instructions of Zenebon et al. (2008), including the usual parameters: i) total fruit weight $(\mathrm{FW})$ and pulp 
weight, determined on precision scale $(0.1 \mathrm{~g}$ precision $)$ and expressed in $\mathrm{g}$; ii) pulp percentage $(\mathrm{P})$, obtained by the ratio between pulp weight and total fruit weight; iii) transverse diameter (TD, region of fruit shoulder), longitudinal diameter (LD, region between peduncle and apex) and skin thickness (ST), measured using a digital caliper $(0.01 \mathrm{~mm}-300 \mathrm{~mm})$ with $0.01 \mathrm{~mm}$ precision and expressed in $\mathrm{mm}$.

For physical-chemical analyses, fruit pulp was analyzed in triplicates for the following parameters: i) $\mathrm{pH}$, determined by potentiometry; ii) soluble solids (SS), in an Abbe-type refractometer, with results expressed in ${ }^{\circ}$ Brix; iii) titratable acidity (TA), expressed in grams of citric acid per $100 \mathrm{~g}$ of pulp, determined by titration with sodium hydroxide $(0.1 \mathrm{~N})$ using $1 \%$ phenolphthalein as indicator, according to the methodology of Zenebon et al. (2008); iv) the soluble solids/titratable acidity ratio (SS/TA) was also calculated; v) ascorbic acid (VIT C), determined according the AOAC method, modified by Benassi \& Antunes (1988), and expressed in mg $100 \mathrm{~g}^{-1}$.

The combined data of both production cycles were subjected to analysis of variance by $\mathrm{F}$ test to find significant effects between the sources of $\mathrm{K}$, whereas $\mathrm{K}$ doses were subjected to quantitative analysis by polynomial regression.

\section{Results and discussion}

According to Table 2, for the physical characteristics, the interaction between $\mathrm{K}$ doses and sources was significant only for fruit weight (FW) and production per plant (PP). For all variables evaluated, expect pulp percentage, there were individual effects of $\mathrm{K}$ sources and doses. $\mathrm{KCl}$ led to the highest values of fruit weight, transverse diameter, longitudinal diameter and skin thickness, whereas $\mathrm{K}_{2} \mathrm{SO}_{4}$ caused highest values of production per plant (Table 2).

As observed in Figures 1A and 1B, the maximum estimated values of fruit weight were $572.3 \mathrm{~g}(94.2 \%$ of the recommended $\mathrm{K}$ dose for $\mathrm{KCl})$ and $532.3 \mathrm{~g}(84.3 \%$ of the recommended $\mathrm{K}$ dose for $\mathrm{K}_{2} \mathrm{SO}_{4}$ ).

The response of fruit weight as a function of doses of potassium chloride $(\mathrm{KCl})$ and potassium sulfate $\left(\mathrm{K}_{2} \mathrm{SO}_{4}\right)$ applied through fertigation can be explained by the active participation of $\mathrm{K}$ in metabolic activities relative to the synthesis and transport of carbohydrates and water to the fruits, thus favoring the increase in weight (RÖMHELD; KIRBY, 2010). At doses higher than the estimated ones, this variable decreased, with possible occurrence of 'luxury consumption', that is, increments in fertilization do not result in increased production by the crop.

Considering the norms of classification for mango fruits with respect to weight (PBMH, 2004), it can be noted that fruits produced by plants fertilized with the maximum estimated dose of $\mathrm{K}_{2} \mathrm{SO}_{4}$ fitted in the class 350
(351 to $550 \mathrm{~g}$ ), whereas those produced under fertilization with $\mathrm{KCl}$ fitted in the class 550 (551 to $800 \mathrm{~g}$ ).

For the production of fruits per plant (PP), $\mathrm{K}_{2} \mathrm{SO}_{4}$ at estimated dose of $97.7 \%$ of the recommendation led to maximum production of $116.4 \mathrm{~kg}$ plant $^{-1}$, which was $13.7 \%$ higher than the maximum production caused by $\mathrm{KCl}\left(100.4 \mathrm{~kg} \mathrm{plant}^{-1}\right)$, at $100 \%$ of the recommendation (Figures $1 \mathrm{C}$ and 1D). The superiority of $\mathrm{K}_{2} \mathrm{SO}_{4}$ for the production per plant is related to the functions of sulfur in the plant, which participates in chlorophyll synthesis and formation of ferredoxin, an electron carrier in photosynthesis, which then favors the accumulation of carbohydrates and other nitrogen compounds (LESTER et al., 2005), preponderant factors in the increase of production per plant. Dutta et al. (2011) observed for 'Amrapali' mango in India that $\mathrm{K}_{2} \mathrm{SO}_{4}$ caused $5 \%$ gain in the number of fruits, compared with $\mathrm{KCl}$.

According to Table 3, it can be observed that there was interaction between $\mathrm{K}$ doses and sources for all physical-chemical variables evaluated, as well as individual effects of the factors, except on SS/TA ratio. Application of $\mathrm{KCl}$ as source of $\mathrm{K}$ led to the highest values of ascorbic acid (VIT C) and soluble solids (SS), whereas $\mathrm{K}_{2} \mathrm{SO}_{4}$ increased the values of $\mathrm{pH}$ and titratable acidity (TA).

Ganeshamurthy et al. (2011) state that fruit quality with respect to size, appearance, color, soluble solids (SS), titratable acidity (TA), vitamin C content, taste (SS/TA ratio) and post-harvest longevity are significantly influenced by the adequate supply of $\mathrm{K}$ due to the direct relationship of this nutrient with processes of photosynthesis, translocation of photosynthates, regulation of stomatal opening and closure and activation of enzymes.

The increase in $\mathrm{K}$ doses applied through fertigation caused different effects on the ascorbic acid content (VIT $\mathrm{C}$ ), depending on the source of $\mathrm{K}$. Increasing doses of $\mathrm{KCl}$ led to linear increase in ascorbic acid production (Figure $2 \mathrm{~A}$ ), whereas $\mathrm{K}_{2} \mathrm{SO}_{4}$ doses caused a Gaussian effect on this variable. Thus, it is possible to observe maximum ascorbic acid content of $6.5 \mathrm{mg} 100 \mathrm{~g}^{-1}$ at the $\mathrm{KCl}$ dose of $150 \%$ of the recommendation (Figure $2 \mathrm{~A}$ ), whereas for $\mathrm{K}_{2} \mathrm{SO}_{4}$ the highest mean of $6.3 \mathrm{mg} 100 \mathrm{~g}^{-1}$ was found at dose equivalent to $71.4 \%$ of the recommendation (Figure 2B). Therefore, $\mathrm{K}_{2} \mathrm{SO}_{4}$ at doses lower than the recommended led to ascorbic acid contents very close to those caused by $\mathrm{KCl}$ at maximum dose $(150 \%)$. The effect of $\mathrm{K}_{2} \mathrm{SO}_{4}$ on this variable can be explained by the fact that $\mathrm{S}$ participates in chlorophyll synthesis and formation of ferredoxin, which acts as electron carrier in photosynthesis, thus favoring the accumulation of carbohydrates and other nitrogen compounds (LESTER et al., 2005), since ascorbic acid is synthesized from sugars produced in the photosynthesis.

Increase in $\mathrm{K}_{2} \mathrm{SO}_{4}$ doses resulted in a linear reduction in pulp $\mathrm{pH}$ (Figure $2 \mathrm{C}$ ). The values shown in 
Figure 2C were superior to those presented by Motta et al. (2015), who recorded pulp pH variation of 3.15-3.88. The studied doses of $\mathrm{K}_{2} \mathrm{SO}_{4}$ led to fruit pulp $\mathrm{pH}$ within the range recommended by Brasil (2000), from 3.3 to 4.5.

Titratable acidity as a function of $\mathrm{KCl}$ and $\mathrm{K}_{2} \mathrm{SO}_{4}$ doses showed interaction and fitted to a Gaussian regression model with four parameters, reaching estimated peaks of 0.43 and $0.47 \mathrm{~g}$ of citric acid $/ 100 \mathrm{~g}$ of pulp for $\mathrm{KCl}$ and $\mathrm{K}_{2} \mathrm{SO}_{4}$, respectively, at doses of 74.6 and $74.2 \%$ of the recommendation (Figures $3 \mathrm{~A}$ and $3 \mathrm{~B}$ ). Hunsche et al. (2003) explained that the increment in $\mathrm{K}$ doses results in accumulation of acidifying substances, possibly related to the contents of organic acids present in the fruits, which depend on plant nutritional balance. Dutta et al. (2011) observed mean values of titratable acidity of 0.24 and 0.27 $\mathrm{g}$ of citric acid/100 $\mathrm{g}$ of pulp caused by $\mathrm{KCl}$ and $\mathrm{K}_{2} \mathrm{SO}_{4}$, respectively. According to the standards of identity and quality of mango fruits established by Brasil (2000), the values of titratable acidity for the maximum estimated doses of $\mathrm{KCl}$ and $\mathrm{K}_{2} \mathrm{SO}_{4}(0.43$ and $0.47 \mathrm{~g}$ of citric acid $/ 100 \mathrm{~g}$ of pulp, respectively) in the present study are at the minimum standard of quality established $(0.32 \%$ of citric acid).

The interaction between the different sources and doses of $\mathrm{K}$ fertilizers was significant for the content of soluble solids (Table 3), but the data did not fit any regression model. $\mathrm{KCl}$ led to mean of $13.6^{\circ} \mathrm{Brix}$ and $\mathrm{K}_{2} \mathrm{SO}_{4}$ resulted in mean of $12.8{ }^{\circ}$ Brix. The contents of soluble solids caused by the doses and sources are within the quality standards, since the minimum value established is $11{ }^{\circ} \mathrm{Brix}$, according to the norms of Brasil (2000).

Silva et al. (2014) stated that the contents soluble solids in Tommy Atkins mango can vary from 8.2 to $14.7^{\circ}$ Brix, depending on pre-harvest factors. The determination of this parameter is of great importance in fruits, for both fresh consumption and industrial processing, since high contents of these constituents in the raw material lead to lower addition of sugars, shorter time of water evaporation, lower expenditure of energy and high agro-industrial yield, resulting in greater saving in the processing (AULAR; NATALE, 2013).

For the ratio between soluble solids and titratable acidity (SS/TA) there was interaction between $\mathrm{K}$ sources and doses, and the data fitted to a quadratic model. The maximum points in the curves were estimated at doses of $102.7 \%$ for $\mathrm{KCl}$ and $80.4 \%$ for $\mathrm{K}_{2} \mathrm{SO}_{4}$, with SS/TA ratios of 39.4 and 39.43, respectively (Figures $3 \mathrm{C}$ and $3 \mathrm{D}$ ). With lower dose of $\mathrm{K}_{2} \mathrm{SO}_{4}(80.4 \%)$ it was possible to obtain a result similar to that obtained with $\mathrm{KCl}(102.7 \%)$. The anion $\mathrm{SO}_{4}^{2-}$ is less leached in the soil than $\mathrm{Cl}^{-}$, so there is higher possibility of absorption, increasing the efficiency of $\mathrm{K}_{2} \mathrm{SO}_{4}$ in comparison with $\mathrm{KCl}$. The use of $\mathrm{K}_{2} \mathrm{SO}_{4}$ reduces $\mathrm{K}$ losses by leaching, increasing the efficiency of the fertilizer (CECÍLIO FILHO; GRANGEIRO, 2004), which may contribute to fruit quality.

Table 1. Chemical characteristics and texture of the soil under irrigated mango cultivation in the $0.0-0.4 \mathrm{~m}$ layer before the experiment.

\begin{tabular}{cccccccccc}
\hline $\mathrm{EC}$ & $\mathrm{OM}$ & $\mathrm{pH}$ & $\mathrm{P}$ & $\mathrm{K}^{+}$ & $\mathrm{Ca}^{2+}$ & $\mathrm{Mg}^{2+}$ & $\mathrm{Na}^{+}$ & $\mathrm{H}+\mathrm{Al}$ & $\mathrm{CEC}$ \\
\hline$\left(\mathrm{dS} \mathrm{m}^{-1}\right)$ & $\left(\mathrm{g} \mathrm{kg}^{-1}\right)$ & $\left(\mathrm{H}_{2} \mathrm{O}\right)$ & $\left(\mathrm{mg} \mathrm{dm}^{-3}\right)$ & $----------------\left(\mathrm{cmol}_{c} \mathrm{dm}^{-3}\right)$ & ---------------- & $\left(\mathrm{dS} \mathrm{m}^{-1}\right)$ \\
\hline 0.18 & 11.0 & 6.8 & 41 & 0.63 & 4.3 & 1.7 & 0.04 & 0.80 & 7,47 \\
\hline $\mathrm{Al}^{3+}$ & $\mathrm{V}$ & $\mathrm{Cu}$ & $\mathrm{Fe}$ & $\mathrm{Mn}$ & $\mathrm{Zn}$ & $\mathrm{Sand}$ & Silt & Clay \\
\hline$\left(\mathrm{cmol}_{c} \mathrm{dm}^{-3}\right)$ & $(\%)$ & $---------\mathrm{mg} \mathrm{dm}^{-3}---------$ & & $----------d a g ~ \mathrm{~kg}^{-1}----------$ \\
\hline 0.00 & 89.00 & 2.0 & 39.4 & 51.7 & 18.9 & 65 & 14 & 21 \\
\hline
\end{tabular}

EC: electrical conductivity of the saturation extract; $\mathrm{P}, \mathrm{K}^{+}$: Mehlich-1; $\mathrm{H}+\mathrm{Al}: 0.5 \mathrm{M}$ calcium acetate at $\mathrm{pH} 7.0 ; \mathrm{Al}^{3+}, \mathrm{Ca}^{2+}, \mathrm{Mg}^{2+}: 1 \mathrm{~mol} \mathrm{~L}^{-1} \mathrm{KCl}$; CEC: cation exchange capacity; OM: soil organic matter; V: Base saturation

Table 2. Summary of analysis of variance for physical characteristics of Tommy Atkins mango fruits as a function of potassium sources and doses.

\begin{tabular}{|c|c|c|c|c|c|c|}
\hline & FW & PP & TD & LD & ST & $\mathrm{P}$ \\
\hline & $-\mathrm{g}-$ & kg plant $^{-1}$ & & $\mathrm{~mm}$ & & $-\%$ \\
\hline Source of K (F value) & $10.41^{* *}$ & $185.0^{* *}$ & $7.52^{*}$ & $8.09^{*}$ & $38.06^{* *}$ & $0.27^{\mathrm{ns}}$ \\
\hline $\mathrm{KCl}$ & $524.7 \mathrm{a}$ & $88.20 \mathrm{~b}$ & $92.85 \mathrm{a}$ & $120.4 \mathrm{a}$ & $1.89 \mathrm{a}$ & $66.63 \mathrm{a}$ \\
\hline $\mathrm{K}_{2} \mathrm{SO}_{-}$ & $507.9 \mathrm{~b}$ & $106.3 \mathrm{a}$ & $90.89 \mathrm{~b}$ & $118.0 \mathrm{~b}$ & $1.61 \mathrm{~b}$ & $66.26 \mathrm{a}$ \\
\hline Doses of K (F value) & $17.07^{* * *}$ & $52.12^{* *}$ & $10.61^{* *}$ & $4.44^{* *}$ & $5.22^{* *}$ & $2.20^{\mathrm{ns}}$ \\
\hline Interaction $(S \times D)$ & $3.54^{*}$ & $6.87^{* *}$ & $0.60^{\mathrm{ns}}$ & $2.57^{\mathrm{ns}}$ & $1.56^{\mathrm{ns}}$ & $0.57^{\mathrm{ns}}$ \\
\hline CV $(\%)$ & 6.24 & 4.33 & 3.01 & 2.70 & 13.58 & 6.34 \\
\hline
\end{tabular}

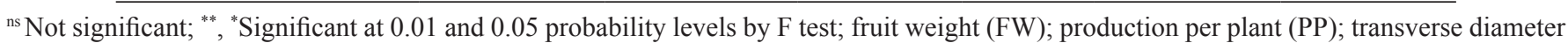
(TD); longitudinal diameter (LD); skin thickness (ST); and pulp percentage (P). 
Table 3. Summary of analysis of variance for physical-chemical characteristics of Tommy Atkins mango fruits as a function of potassium sources and doses.

\begin{tabular}{lccccc}
\hline & VIT C & $\mathrm{pH}$ & $\mathrm{TA}$ & $\mathrm{SS}$ & $\mathrm{SS} / \mathrm{TA}$ \\
\hline & $\mathrm{mg} 100 \mathrm{~g}^{-1}$ & & ${\mathrm{~g} 100 \mathrm{~g}^{-1}}^{\left({ }^{\circ} \mathrm{Brix}\right)}$ & \\
\hline Source of K (F value) & $9.88^{*}$ & $72.2^{* *}$ & $11.4^{*}$ & $394.7^{* *}$ & $5.52^{\text {ns }}$ \\
$\mathrm{KCl}$ & $5.83 \mathrm{a}$ & $4.00 \mathrm{~b}$ & $0.41 \mathrm{~b}$ & $13.6 \mathrm{a}$ & $37.90 \mathrm{a}$ \\
$\mathrm{K}_{2} \mathrm{SO}_{4}$ & $5.49 \mathrm{~b}$ & $4.11 \mathrm{a}$ & $0.42 \mathrm{a}$ & $12.8 \mathrm{~b}$ & $36.90 \mathrm{a}$ \\
Doses of K (F value) & $7.39^{* *}$ & $9.80^{* *}$ & $7.78^{* *}$ & $47.2^{* *}$ & $12.26^{* *}$ \\
Interaction (S x D) & $14.2 * *$ & $19.3^{* *}$ & $7.74^{* *}$ & $137.1 * *$ & $16.74^{* *}$ \\
$\mathrm{CV}(\%)$ & 5.29 & 1.03 & 4.19 & 0.80 & 3.97 \\
\hline
\end{tabular}

${ }^{\text {ns }}$ Not significant; ${ }^{* *}$, "Significant at 0.01 and 0.05 probability levels by F test; vitamin C (VIT C); titratable acidity (TA); soluble solids (SS); SS/TA ratio.
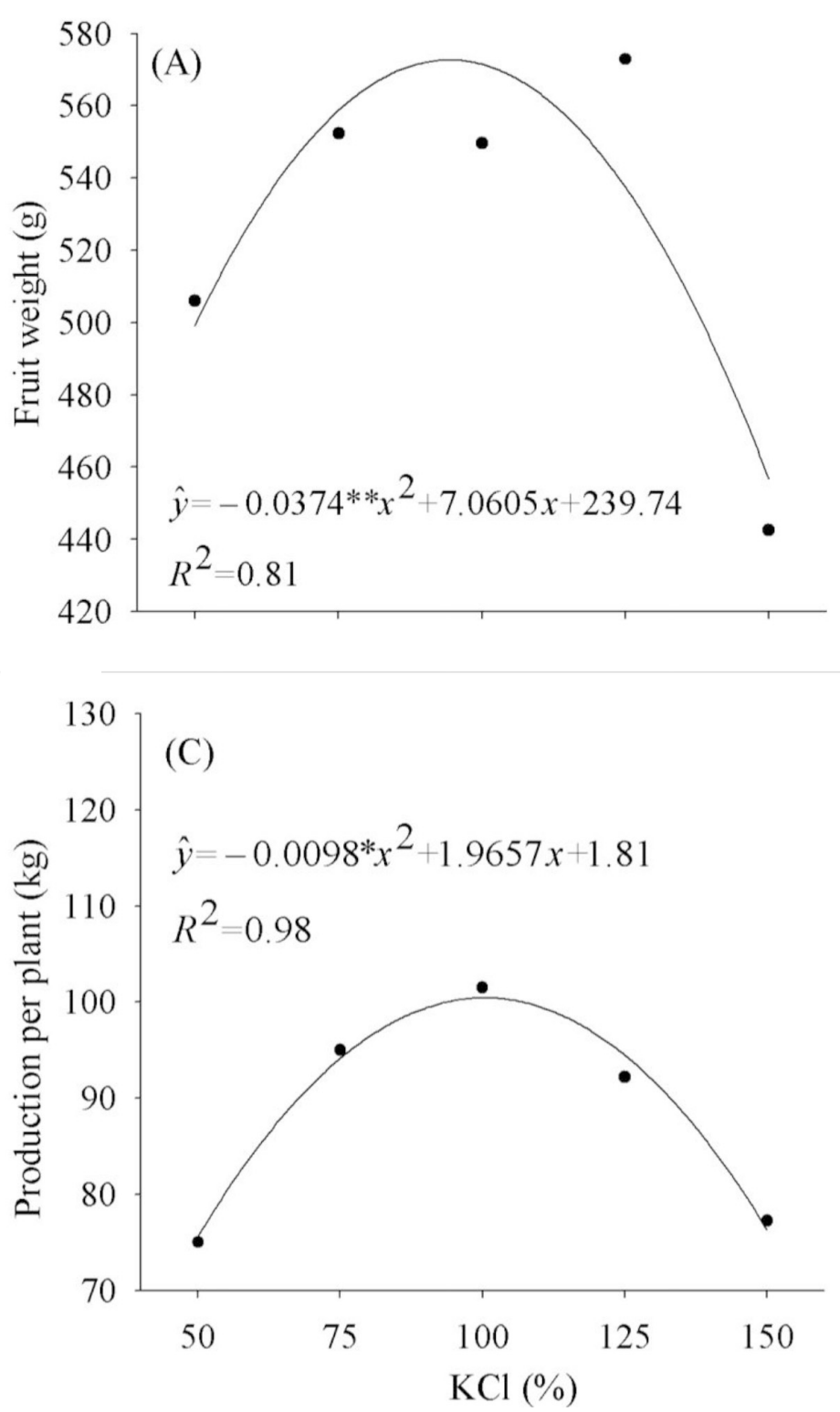

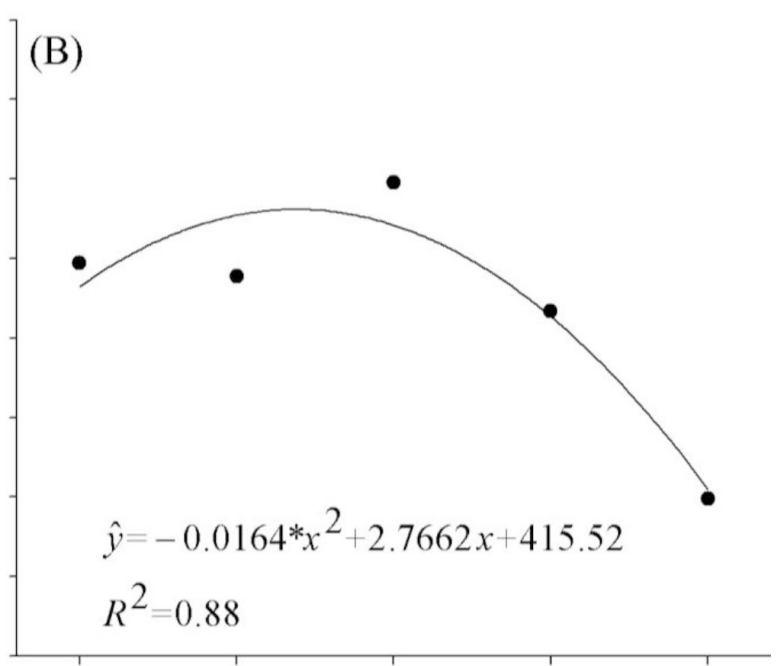

(D)

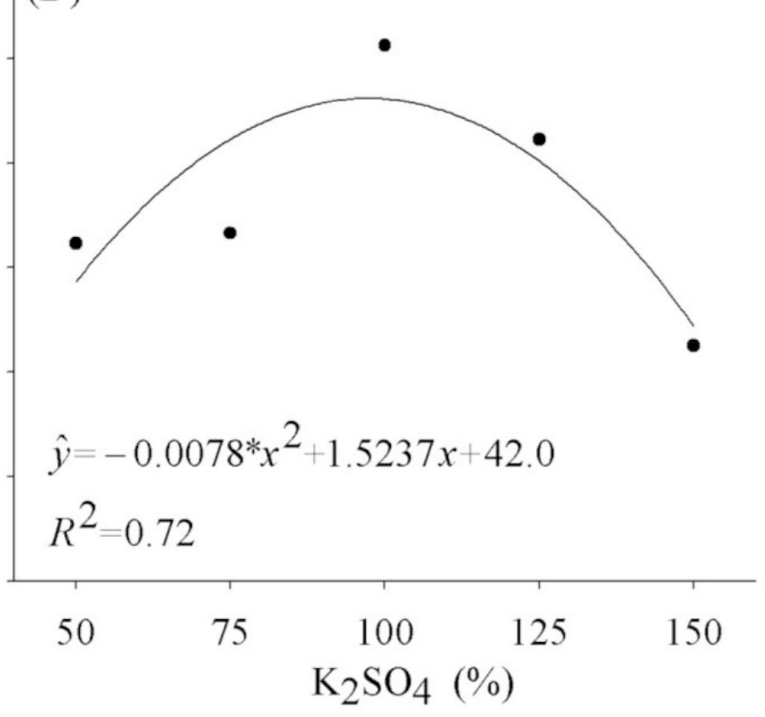

Figure 1. Fruit weight and production of Tommy Atkins mango under fertigation with difference sources $(\mathrm{KCl}$ and $\mathrm{K}_{2} \mathrm{SO}_{4}$ ) and doses of potassium. 

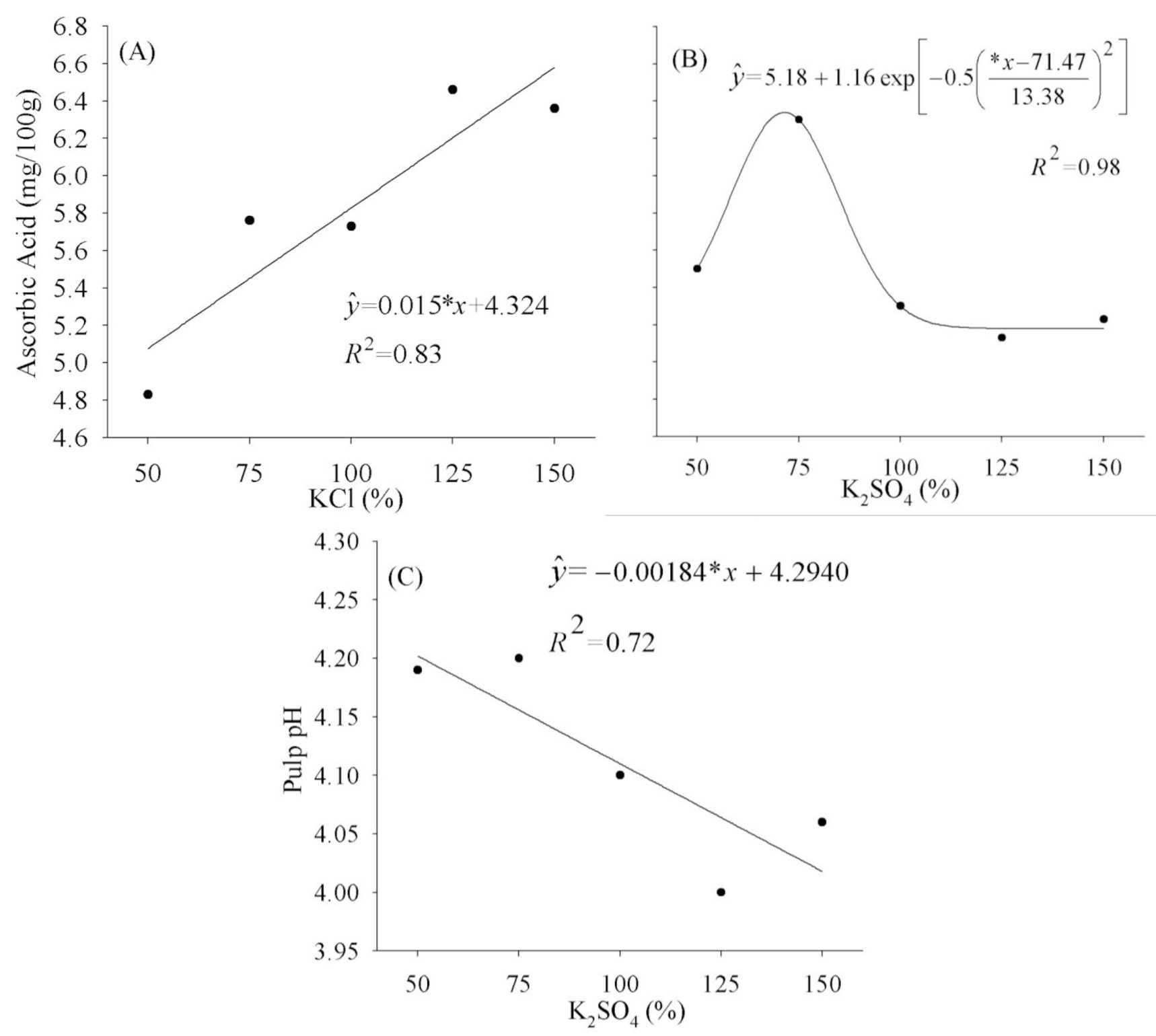

Figure 2. Contents of ascorbic acid (A and B) and pulp pH (C) in Tommy Atkins mango fruits under fertigation with different sources and doses of potassium. 

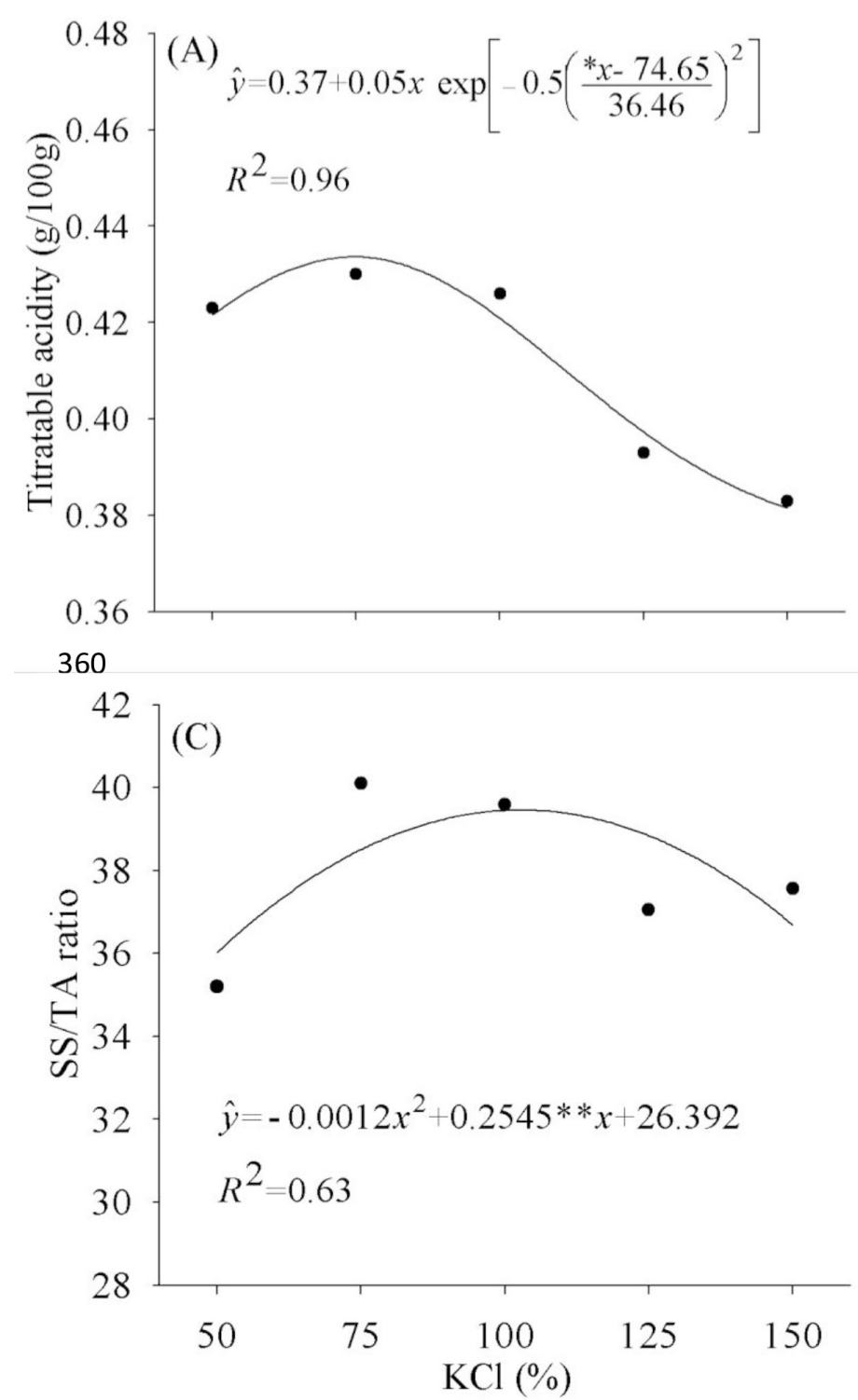
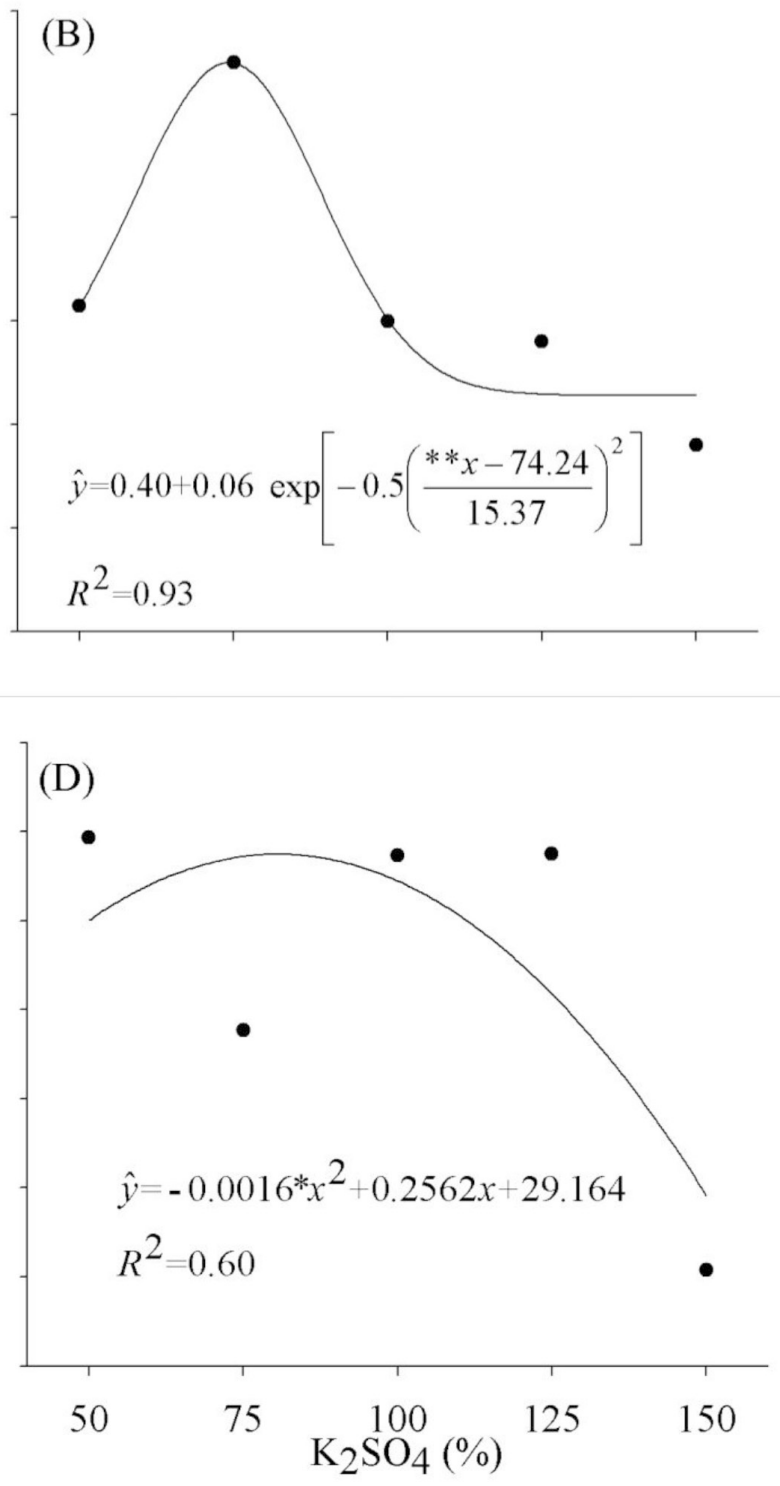

Figure 3. Titratable acidity (A and B) and SS/TA ratio (C and D) in Tommy Atkins mango fruits under fertigation with different sources and doses of potassium.

\section{Conclusions}

Potassium sources and doses have effect on fruit weight, production per plant, vitamin $\mathrm{C}, \mathrm{pH}$, titratable acidity, soluble solids and soluble solids/titratable acidity ratio in Tommy Atkins mango.

Fertilization with potassium chloride leads to higher weight of mango fruits, whereas fertilization with potassium sulfate causes higher production of mango fruits per plant. Doses lower than the recommendation of potassium sulfate result in higher contents of ascorbic acid in mango fruits.

The dose of $97.7 \%$ of the recommendation $(349 \mathrm{~g}$ plant-1) of potassium sulfate, for the conditions under which the experiment was conducted, led to the minimum quality required in Tommy Atkins mango fruits with respect to the physical-chemical characteristics evaluated.

\section{References}

ALMEIDA, E.V.D.; FERNANDES, F.M.; CAIONE, G.; PRADO, R. de M.; BOLIANI, A.C.; CORRÊA, L.D.S. Liming. In: Growing mango cultivar Keitt in production. Communications in Soil Science and Plant Analysis, Londres, v.46, n.4, p.430-438, 2015.

AMORIM, D.A.; ROZANE, D.E.; SOUZA, H.A.; MODESTO, V.C.; NATALE, W. Adubação nitrogenada e potássica em goiabeiras 'Paluma': I. Efeito na produtividade e na qualidade dos frutos para industrialização. Revista Brasileira de Fruticultura, Jaboticabal, v.37, n.1, p.201209, 2015. 
AULAR, J.; NATALE, W. Nutrição mineral e qualidade do fruto de algumas frutíferas tropicais: goiabeira, mangueira, bananeira e mamoeiro. Revista Brasileira de Fruticultura, Jaboticabal, v.35, n.4, p.1214-1231, 2013.

BENASSI, M.T.; ANTUNES, A.J. A comparison of metaphosphoric and oxalic acids as extractant solutions for the determination of vitamin $\mathrm{C}$ in selected vegetables. Arquivos de Biologia e Tecnologia, Curitiba, v.31, n.4, p.507-513, 1988.

BRASIL. Instrução normativa $\mathrm{n}^{\circ} 1$, de 7 de janeiro de 2000/MAPA. Regulamento técnico geral para fixação dos padrões de identidade e qualidade para polpa de frutas. Diário Oficial da União, Poder Executivo, Brasília, DF, 10 jan. 2000.

CAETANO, L.C.S.; VENTURA, J.A.; COSTA, A.F.S.; GUARÇONI, R.C. Efeito da adubação com nitrogênio, fósforo e potássio no desenvolvimento, na produção e na qualidade de frutos do abacaxi 'Vitória'. Revista Brasileira de Fruticultura, Jaboticabal, v.35, n.3, p.883890, 2013.

CARNEIRO, M.A.; LIMA, A.M.N.; CAVALCANTE, Í.H.L.; CUNHA, J.C.; RODRIGUES, M.S.; LESSA, T.B.S. Soil salinity and yield of mango fertigated with potassium sources. Revista Brasileira de Engenharia Agrícola e Ambiental, Campina Grande, v.21, n.5, p.310316, 2017.

CAVALCANTE, I.H.L.; LIMA, A.M.N.; CARNEIRO, M.A.; RODRIGUES, M.S.; SILVA, R.L. Potassium doses on fruit production and nutrition of mango (Mangifera indica L.) cv. Palmer. Revista de la Facultad de Agronomia de la Universidad del Zulia, Maracaibo, v.34, n.4, p.385-399, 2016.

CECÍllo FILHO, A.B.; GRANGEIRO, L.C. Produtividade da cultura da melancia em função de fontes e doses de potássio. Revista Ciência e Agrotecnologia, Lavras, v.28, n.3, p.561-569, 2004.

COSTA, M.E.; CALDAS, A.V.C.; SOUZA, W.C.M.; GURGEL, M.T.; SILVA, R.M. Caracterização nutricional da mangueira 'Tommy Atkins' sob adubação potássica. Revista Verde de Agroecologia e Desenvolvimento Sustentável, Pombal, v.6, n.2, p.125-130, 2011.

DUTTA, P.; AHMED, B.; KUNDU, S. Effect of different sources of potassium on yield, quality, and leaf mineral content of mango. Journal Better Crops With Plant Food, Norcross, v.5, n.1, p.16-18, 2011.
GANESHAMURTHY,A.N.; SATISHA, G.C.; PRAKASH, P. Potassium nutrition on yield and quality of fruit crops with special emphasis on banana and grapes. Journal of Agricultural Sciences, Toronto, v.24, n.1, p.29-38, 2011.

GENÚ, P.J.C.; PINTO, A.C.A. A Cultura da mangueira. Brasília, DF: Embrapa Informação Tecnológica, 2002. p.452.

HUNSCHE, M.; BRACKMANN, A.; EMANI, P.R. Efeito da adubação potássica na qualidade pós-colheita de maçãs Fuji. Pesquisa Agropecuária Brasileira, Brasília, DF, v.38, n.4, p.489-496, 2003.

LESTER, G. E.; JIFON, J. L.; ROGERS, G. Supplemental foliar potassium applications during muskmelon fruit development can improve fruit quality, ascorbic acid, and beta-carotene contents. Journal of the American Society for Horticultural Science, Alexandria, v.130, n.4, p.649-653, 2005.

MOTTA, J.D.; QUEIROZ, A.J.M.; FIGUEIRÊDO, R.M.F.; SOUSA, K.S.M. Índice de cor e sua correlação com parâmetros físico-químicos de goiaba, manga e mamão. Comunicata Scientiae, Bom Jesus, v.6, n.1, p.74-82, 2015.

OLIVEIRA, H.T.B.; PEREIRA, E.C.; MENDONÇA, V.; SILVA, R.M.; LEITE, G.A.; DANTAS, L.L.G.R. Produção e qualidade de frutos de mangueira "Tommy Aktins" sob doses de Paclobutrazol. Agropecuária Científica no Semiárido, Campina Grande, v.10, n.3, p.89-92, 2014.

PBMH - Programa Brasileiro para a Modernização da Horticultura. Normas de Classificação de Manga. São Paulo: Centro de Qualidade em Horticultura (CEAGESP), 2004. 6p. 2004. (Documento, 28).

PINTO, P.A.C.; DIAS, L.E.; ALVAREZ, V.H.V.; CHOUDHURY, M.M.; VIEIRA, G. Avaliação do estado nutricional da mangueira 'Tommy Atkins' no submédio do vale do rio São Francisco: cálculo dos índices DRIS.

Recursos Rurais, Lugo, v.5, n.6, p.5-13, 2010.

RÖMHELD, V.; KIRBY, E.A. Research on potassium in agriculture: needs and prospects. Plant and Soil, Dordrecht, v.335, n.1-2, p.155-180, 2010.

SANTOS, H.G.; JACOMINE, P.K.T.; ANJOS, L.H.C.; 
OLIVEIRA, V.A.; LUMBRERAS, J.F.; COELHO, M.R.; ALMEIDA, J.A.; CUNHA, T.J.F.; OLIVEIRA, J.B. Sistema brasileiro de classificação de solos. 3.ed. Rio de Janeiro: Embrapa Solos, 2013. p.353.

SILVA, A.C.; SOUZA, A.P.; LEONEL, S. Growth and flowering of five mango cultivar under subtropics conditions of Brazil. American Journal of Plant Sciences, Irvine, v.5, n.3, p.393- 402, 2014.
SILVA, F. C. Manual de análises químicas de solos, plantas e fertilizantes. 2.ed. Brasília: Embrapa Comunicação para Transferência de Tecnologia, 2009. p. 627 .

ZENEBON, O.; PASCUET, N.S.; TIGLEA, P. Métodos físico-químicos para análise de alimentos. 4.ed. São Paulo: Instituto Adolfo Lutz, 2008. p.1002. 